\title{
Adhesion of Epiphany and AH Plus Sealers to Human Root Dentin Treated with Different Solutions
}

\author{
Vinicius Humberto NUNES ${ }^{1}$ \\ Ricardo Gariba SILVA ${ }^{1}$ \\ Edson ALFREDO 1 \\ Manoel D. SOUSA-NETO ${ }^{2}$ \\ Yara T. C. SILVA-SOUSA ${ }^{1}$

\begin{abstract}
${ }^{1}$ School of Dentistry, University of Ribeirão Preto, Ribeirão Preto, SP, Brazil
${ }^{2}$ Department of Restorative Dentistry, School of Dentistry of Ribeirão Preto, University of São Paulo, Ribeirão Preto, SP, Brazil
\end{abstract}

\begin{abstract}
This study evaluated comparatively the adhesion of Epiphany and AH Plus endodontic sealers to human root dentin treated with $1 \%$ $\mathrm{NaOCl}$ and $1 \% \mathrm{NaOCl}+17 \%$ EDTA, using the push-out test. Sixty root cylinders obtained from maxillary canines had the canals prepared and were randomly assigned to 3 groups $(n=20)$, according to root dentin treatment: GI - distilled water (control), GII - $1 \%$ $\mathrm{NaOCl}$ and $\mathrm{GIII}-1 \% \mathrm{NaOCl}+17 \%$ EDTA. Each group was divided into 2 subgroups $(\mathrm{n}=10)$ filled with either Epiphany or AH Plus. Bond strength push-out test data $(\mathrm{kN})$ were obtained and analyzed statistically by ANOVA and Tukey's post-hoc test. There was statistically significant difference between sealers (AH Plus: $0.78 \pm 0.13$; Epiphany: $0.61 \pm 0.19$; $\mathrm{p}<0.01$ ) and among root dentin treatments (distilled water: $0.58 \pm 0.19 ; 1 \% \mathrm{NaOCl}: 0.71 \pm 0.12 ; 1 \% \mathrm{NaOCl}+17 \%$ EDTA: $0.80 \pm 0.17 ; \mathrm{p}<0.05$ ). In conclusion, AH Plus sealer presented greater adhesion to dentin than Epiphany, regardless of the treatment of root canal walls.
\end{abstract}

Key Words: root canal sealer, adhesion, $\mathrm{NaOCl}$, EDTA, push-out test.

\section{INTRODUCTION}

Advances in adhesive technology have reinforced the search for means to minimize apical and coronal marginal leakage by increasing the sealing between the filling material and the root canal walls (1). A dual-curable methacrylate resin sealer composed of fillers of calcium hydroxide, barium sulphate, barium glass and silica (Epiphany; Pentron Clinical Technologies, Wallingford, CT, USA) has been developed for use with a self-etching primer and in association with a new thermoplastic synthetic polyester polymer-based root canal filling material (Resilon; Resilon Research LLC, Madison, CT, USA) that replaces gutta-percha. Obturation using the Epiphany/Resilon system is claimed to create a tight seal with the dentinal tubules within the root canal system. In essence, it produces a "monoblock" effect, where the core material (Resilon), sealer (Epiphany) and dentinal tubules become a single solid structure (2-4). Shipper et al. (2) have suggested that this monoblock would be highly desirable to provide a thorough seal of the root canal system as it would be able to minimize coronal leakage in case of loss or fracture of the temporary coronal restoration. In vitro (2) and in vivo (5) studies have demonstrated a good resistance of the Epiphany/Resilon monoblock system to bacterial leakage.

Epoxy resin-based cements have also presented a good performance as root canal sealers. AH Plus (De Trey-Dentsply, Konstanz, Germany) has been shown to have low solubility and disintegration (4) and good adhesion (6). 
Several chemical substances used as irrigants during biomechanical preparation of the root canal system might affect the characteristics of dentin substrate. Among the most commonly used irrigants, sodium hypochlorite $(\mathrm{NaOCl})$ presents capacity of dissolution of organic tissues, saponification of fats and neutralization of toxic products as well as antimicrobial and deodorizing action (7) while ethylenediaminetetraacetic acid disodium salt (EDTA) has a calcium ion chelating capacity and promotes dentin demineralization and smear layer removal (8).

The aim of this study was to evaluate comparatively the adhesion of Epiphany and AH Plus endodontic sealers to human root dentin treated with $1 \% \mathrm{NaOCl}$ and $1 \% \mathrm{NaOCl}+17 \%$ EDTA, using the push-out test.

\section{MATERIAL AND METHODS}

Sixty extracted sound human maxillary human canines were sectioned transversally at the cementoenamel junction and apically at the root end to leave an approximately 8 -mm-thick cylinder that was then centred inside an aluminium ring $(16 \mathrm{~mm}$ diameter and $8 \mathrm{~mm}$ high) and embedded in acrylic resin.

The aluminium rings containing the dentin cylinders were placed in a parallelometer and their coronal and apical surfaces were flattened and made parallel, until a final length of $8 \mathrm{~mm}$ was obtained. The root canals of each specimen were prepared using a tapered diamond bur (893-047, Brasseler, Savannah, GA, USA) at a low-speed handpiece, which was attached to the arm of the parallelometer. This arm was lowered to a depth previously determined by a silicone stop and space for sealer placement was created with the following standardised dimensions: larger diameter $=3.3 \mathrm{~mm}$, smaller diameter $=2.6 \mathrm{~mm}$, and length $=8 \mathrm{~mm}$. During preparation, canals were irrigated with distilled water.

The specimens were randomly assigned to 3 groups of 20 teeth each and root canal dentin was submitted to the following treatments: Group I - irrigation with $20 \mathrm{~mL}$ distilled water and drying with sterile absorbent paper points (Dentsply-Herpo, Petrópolis, RJ, Brazil); Group II - a final flush with $20 \mathrm{~mL}$ distilled water and drying with sterile absorbent paper points; Group III - irrigation with $5 \mathrm{~mL} 1 \% \mathrm{NaOCl}$ for $30 \mathrm{~min}$ (changing the solution every $5 \mathrm{~min}$ ) followed by irrigation with $5 \mathrm{~mL} 17 \%$ EDTA for $5 \mathrm{~min}$. Next, the specimens received a final flush with $20 \mathrm{~mL}$ distilled water and were dried with sterile absorbent paper points. After surface treatment, each group were divided into 2 subgroups $(n=10)$, according to the root canal sealer used: Epiphany and AH Plus. For the subgroups filled with Epiphany, the self-etching primer supplied in the product's kit was first applied to root dentin and the sealer was dispensed directly from the tip of its automix dual-chamber syringe, according to the manufacturer's instructions. For the subgroups filled with AH Plus, the sealer was prepared and dispensed with a Centrix injector (Centrix Inc, Shelton, CT, USA).

Subsequently, the specimens were dried and fixed securely in a metallic apparatus by two screws in the horizontal plane. For the test, a stainless steel support was used to hold the specimens (metallic ring + dentin cylinder) in the Instron 4444 universal testing machine (Instron Corporation, Canton, MA, USA) in such a way that the side with the smaller diameter of the root canal faced upwards and was aligned to the shaft that would exert pressure load on the sealer (apicalcoronally) (Fig. 1). The tip of apparatus used for load application in the push-out test had $1.8 \mathrm{~mm}$ diameter and the smaller end of the dentin cylinder (where the tip was placed) had $2.6 \mathrm{~mm}$ diameter, leaving a thin sealer layer $(0.4 \mathrm{~mm})$ surrounding the tip. This method assured the alignment of the specimen in a reproducible manner, and also avoided contact of the shaft with the dentin during testing. The machine was calibrated at a constant speed of $1 \mathrm{~mm} \mathrm{~min}^{-1}$. The load required to cause failure of the bond was recorded in $\mathrm{kN}$. Data were submitted to statistical analysis by ANOVA and Tukey's test $(\alpha=0.05)$.

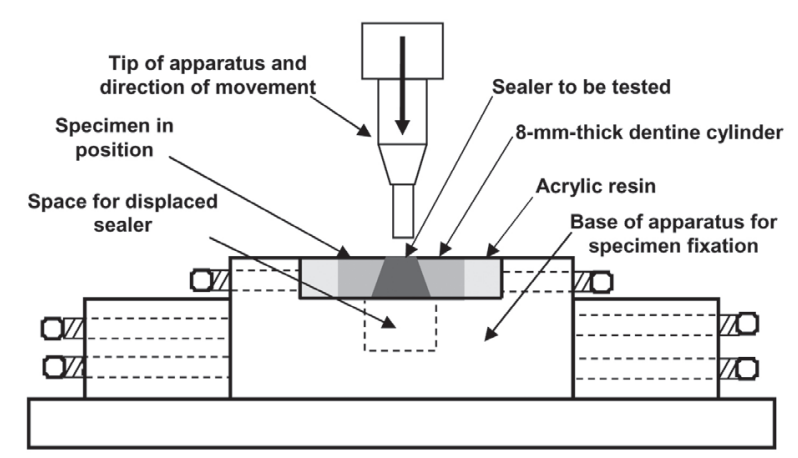

Figure 1. Scheme of the specimen positioned on the apparatus for alignment and load application in the Instron 4444 universal testing machine. 


\section{RESULTS}

Push out bond strength means (in $\mathrm{kN}$ ) and standard deviations are given in Table 1.

There was statistically significant difference $(\mathrm{p}<0.01)$ between the sealers: AH Plus $(0.780 \pm 0.135)$ and Epiphany $(0.613 \pm 0.189)$. There was also statistically significant difference $(\mathrm{p}<0.05)$ among the root dentin treatments: distilled water $(0.58 \pm 0.194) ; 1 \%$ $\mathrm{NaOCl}(0.71 \pm 0.117) ; 1 \% \mathrm{NaOCl}+17 \%$ EDTA $(0.80$ $\pm 0.167)$. However, no statistically significant difference $(p>0.05)$ was found for the sealer $x$ surface treatment interaction.

\section{DISCUSSION}

Adhesion is defined as a process in which two surfaces of different molecular compositions are bonded by chemical, physical or mechanical attraction forces (9). Mechanical adhesion occurs by entrapment of a material into another body, within natural or artificial cavities. Chemical adhesion may result from primary valence forces, such as covalent and metallic bonds. Physical adhesion, in turn, relies on secondary valence forces, like Van der Walls forces, London dispersion forces and hydrogen bonds (10). For adhesion to occur, it is necessary that the materials to be adhered are sufficiently close to each other. Therefore, a primary condition is the wettability of the liquid in a solid material (11), which will provide the required proximity between the materials, facilitating molecular attraction and promoting adhesion (9).

Adhesion of an endodontic sealer is defined as its capacity to adhere to the root canal walls and promote the union of gutta-percha cones to each other and to the dentin $(6,12)$. Some variables may interfere with the outcome and understanding of sealer adhesion to root canal walls, namely the employed methodology, treatment of dentin surface and type of material. The lack of

Table 1. Means (in $\mathrm{KN}) \pm$ SD for displacement of the sealers from root dentin after surface treatment.

\begin{tabular}{lccc}
\hline & $\begin{array}{c}\text { Distilled } \\
\text { water }\end{array}$ & $1 \% \mathrm{NaOCl}$ & $\begin{array}{c}1 \% \mathrm{NaOCl}+ \\
17 \% \mathrm{EDTA}\end{array}$ \\
\hline Epiphany & $0.47 \pm 0.22$ & $0.69 \pm 0.13$ & $0.68 \pm 0.12$ \\
AH Plus & $0.69 \pm 0.06$ & $0.73 \pm 0.10$ & $0.92 \pm 0.11$ \\
\hline
\end{tabular}

ADA's specific guidelines for adhesion tests with root canal sealers led to the development of a wide array of experimental models without standardization.

Sousa-Neto et al. (6) developed a methodology that permits evaluating the adhesive capacity of endodontic sealers using as test surface the root canal dentin of root cylinders. This experimental model allows understanding how adhesion to root dentin occurs under conditions closer to clinical use. The sealer is placed in direct contact with the root canal dentin in its original anatomic shape, instead of a flat surface obtained form tooth crowns, which presents a different tubule arrangement. Therefore, when the specimen is filled with sealer, the material adapts to the canal shape and penetrates into the dentinal tubules, promoting a mechanical retention similar to that obtained in a rootfilled tooth. The force obtained with this model is thus derived from shear strength rather then pure tensile strength using a universal testing machine that allows standardizing the test, making it reproducible and more reliable, as reported elsewhere (13).

Regarding the treatment of dentin surface, in the present study, the use of a chelating agent (EDTA) for treatment of the root canal walls resulted in higher adhesion values of the sealers to dentin. It is more likely to have occurred because, according to Hülsmann et al. (8), EDTA is able to act on tooth mineral matrix and promote removal of the smear layer formed during biomechanical preparation, which allow a better penetration of sealers into the dentinal tubules, increasing the contact surface of the filling material with dentin.

The specimens treated with $1 \% \mathrm{NaOCl}$ presented intermediate adhesion values of the sealers to root canal dentin. This can probably be attributed to the fact that the smear layer was not completely eliminated from dentin because this amorphous layer is composed by organic and inorganic debris (14) and $\mathrm{NaOCl}$ acts selectively on the removal of organic particles (7). The excellent organic tissue-dissolving property of $\mathrm{NaOCl}$ is due to the presence of sodium hydroxide and hypochlorous acid in its composition, but this substance cannot dissolve inorganic particles and therefore does not effectively remove the smear layer formed on canal walls after biomechanical preparation.

In the specimens filled with Epiphany, $1 \% \mathrm{NaOCl}$ could also have interfered with the polymerization of the self-etching primer, as described by Lai et al. (15), thus compromising sealer adhesion to dentin. 
The specimens in which dentin surface was irrigated with distilled water presented the lowest adhesion values, probably because dentin surface remained covered with the smear layer produced during canal preparation. These results confirm that the presence of smear layer affects negatively the adhesion of root canal sealers because it forms an interface between the sealing material and dentin, hindering or impeding sealer penetration into the dentinal tubules (16).

AH plus had greater adhesion to root dentin than Epiphany. This is likely due to the fact that, as an epoxy resin-based sealer, AH Plus has better penetration into the microirregularities because of its creep capacity and long setting time, which increases the mechanical interlocking between sealer and root dentin. This fact, allied to the cohesion among sealer molecules, increases the resistance to removal and/or displacement from dentin (17), which can be translated as greater adhesion.

The results obtained with Epiphany in this study did not meet the expectations regarding its adhesion to root dentin, probably due to the following reasons: sealer polymerization at sealer/dentin interface may have been affected by oxygen present in the root canal walls and dentinal tubules. According to Franco et al. (18), the oxygen inhibits vinyl polymerization in composite resins and 40-60\% of the carbon bonds remained unsaturated (12). This rationale had been described by Rueggeberg and Margeson (19), who stated the oxygen produces a fine polymeric film with low polymerization degree. It is likely that the presence of this layer inhibited Epiphany setting at sealer/dentin interface and within the dentinal tubules. In addition, failures at the sealer-dentin interface may also occur due to the polymerization of the methacrylate-based resin sealer immediately after its placement into the root canal (1). The coronal photoactivation of the sealer, following manufacturer's instructions, may reduce its creep capacity. We understand that a higher sealer flow would allow a greater contact with the primer and hence a greater mechanical interlocking with dentin. A SEM study (1) demonstrated that primer was found in all root canal thirds (cervical, middle and apical), which reinforces the statement that failure recorded at sealer/dentin interface is more likely to be related to the sealer and not to primer application. Another aspect that could interfere in the polymerization reaction of a root canal sealer is its incomplete photoactivation in the whole extension of the specimen, which results in the presence of unreacted residual monomers in the deepest portion of the specimen.

Another aspect that should be considered in the analysis of the obtained results is that the goal of this study was to evaluate the adhesion of Epiphany sealer to root dentin submitted to different treatments. Therefore, the Epiphany/Resilon system was not used in this experimental model because its monoblock effect could have interfered with the adhesion values (20).

The adhesion of root canal sealers has been investigated $(6,12)$. However, there has been little discussion regarding the most adequate methodology for studying this property and the actual role of sealer adhesion to dentin in the final outcome of root canal filling. Teixeira et al. (20) opened the perspectives for understanding this property when stated that, because of their claim of a more effective union to dentin with use of a self-etching primer and formation of a monoblock system, methacrylate resin-based sealers may increase root resistance to fracture in endodontically treated teeth. This may be a great advantage of these materials as long as the physicochemical proprieties of the sealer are accommodated by the manufacturer.

In the present study, AH Plus sealer presented greater adhesion to dentin than Epiphany, regardless of the treatment of root canal walls.

\section{RESUMO}

O objetivo do presente estudo foi avaliar a adesividade do cimento Epiphany à dentina radicular previamente tratada com hipoclorito de sódio a $1 \%$ e EDTA a $17 \%$, em comparação ao cimento AH Plus, pelo método do "push-out". Foram preparados sessenta cilindros de raízes de caninos superiores humanos que foram distribuídos em 3 grupos $(n=20)$ de acordo com o tratamento da dentina: GI - água destilada (controle), GII - hipoclorito de sódio $1 \%$ e GIII - EDTA $17 \%$. Esses grupos de corpos-de-prova foram distribuídos em 2 subgrupos para receber os cimentos obturadores a serem testados: Ephiphany e AH Plus. Foi realizado o teste do "push-out" e os resultados (em $\mathrm{kN}$ ) foram analisados estatisticamente por ANOVA e o teste "post-hoc" de Tukey. A análise demonstrou diferença estatisticamente significativa entre os cimentos (AH Plus: 0,78 $\pm 0,13$; Epiphany: 0,61 $\pm 0,19$; $\mathrm{p}<$ 0,01 ) e entre as soluções testadas (água destilada: 0,58 $\pm 0,19$; $\mathrm{NaOCl}: 0,71 \pm 0,12$; EDTA: 0,80 $\pm 0,17 ; \mathrm{p}<0,05)$. Conclui-se que o cimento $\mathrm{AH}$ Plus apresentou valores de adesividade superiores aos obtidos pelo cimento Epiphany, independente do tratamento realizado nas paredes dos canais radiculares.

\section{REFERENCES}

1. Tay FR, Loushine RJ, Weller RN, Kimbrough WF, Pashley $\mathrm{DH}$, Mak YF, et al. Ultrastructural evaluation of the apical 
seal in roots filled with a polycaprolactone-based root canal filling material. J Endod 2005;31:514-519.

2. Shipper G, Ørstavik D, Teixeira FB, Trope M. An evaluation of microbial leakage in roots filled with a thermoplastic synthetic polymer-based root canal filling material (Resilon). J Endod 2004;30:342-347.

3. Ezzie E, Fleury A, Solomon E, Spears R, He J. Efficacy of retreatment techniques for a resin-based root canal obturation material. J Endod 2006;32:341-344.

4. Versiani MA, Carvalho-Junior JR, Padilha MIAF, Lacey S, Pascon EA, Sousa-Neto MD. A comparative study of physicochemical properties of AH Plus and Epiphany root canal sealants. Int Endod J 2006;39:464-471.

5. Shipper G, Teixeira FB, Arnold RR, Trope M. Periapical inflammation after coronal microbial inoculation of dog roots filled with gutta-percha or Resilon. J Endod 2005;31:91-96.

6. Sousa-Neto MD, Coelho FI, Marchesan MA, Alfredo E, SilvaSousa YTC. In vitro study of the adhesion of an epoxy based sealer to human dentine submitted to irradiation with Er:YAG and Nd:YAG lasers. Int Endod J 2005;38:866-870.

7. Guerisoli DMZ, Marchesan MA, Walmsley PJ, Pécora JD. Evaluation of smear layer removal by EDTA and sodium hypochlorite with ultrasonic agitation. Int Endod $\mathbf{J}$ 2002;35:418-421.

8. Hülsmann M, Heckendorff M, Lennon A. Chelating agents in root canal treatment: mode of action and indications for their use. Int Endod J 2003;36:810-830.

9. Erickson RL. Surface interactions of dental adhesive materials. Oper Dent 1992;5:81-94.

10. Nakabayashi N, Pashley D. Hybridization of dental hard tissues. Tokyo: Quintessence Publishing Co., 2000.

11. Anusavice KJ. Phillips' science of dental materials. 11th ed. Philadelphia: CV Saunders, 2003.
12. Sousa-Neto MD, Passarinho-Neto JG, Carvalho-Júnior JR, Cruz-Filho AM, Pécora JD, Saquy PC. Evaluation of the effect of EDTA, EGTA and CDTA on dentin adhesiveness and microleakage with different root canal sealers. Braz Dent J 2002;13:123-128.

13. Ørstavik D. Physical properties of root canal sealers: measurement of flow, working time, and compressive strength Int Endod J 1983;16:99-107.

14. Torabinejad M, Cho Y, Khademi AA, Bakland LK, Shabahang S. The effect of various concentrations of sodium hypochlorite on the ability of MTAD to remove the smear layer. J Endod 2003;29:233-239.

15. Lai SC, Mak YF, Cheung GS, Osorio R, Toledano M, Carvalho RM, et al.. Reversal of compromised bonding to oxidized etched dentin. J Dent Res 2001;80:1919-1924.

16. White RR, Goldman M, Lin PS. The influence of the smeared layer upon dentinal tubule penetration by endodontic filling materials. Part II. J Endod 1987;13:369-374.

17. Sousa-Neto MD, Marchesan MA, Pécora JD, Brugnera-Junior A, Silva-Sousa YTC, Saquy PC. Effect of Er:YAG laser on adhesion of root canal sealers. J Endod 2002;28:185-187.

18. Franco EB, Lopes LG, D'Alpino PH, Pereira JC, Mondelli RF, Navarro MF. Evaluation of compatibility between different types of adhesives and dual-cured resin cement. J Adhes Dent 2002;4:271-275

19. Rueggeberg FA, Margeson DH. The effect of oxygen inhibition on an unfilled/filled composite system. J Dent Res 1990;69:1652-1658

20. Teixeira FB, Teixeira ECN, Thompson J, Trope M. Fracture resistance of roots endodontically treated with a new filling material. J Am Dent Assoc 2004;135:646-652.

Accepted June 4, 2007 